\title{
Parasitism, the Diversity of Life, and Paleoparasitology
}

\section{Adauto Araújo/ ${ }^{+}$, Ana Maria Jansen*, Françoise Bouchet**, Karl Reinhard***, Luiz Fernando Ferreira}

\author{
Escola Nacional de Saúde Pública-Fiocruz, Rua Leopoldo Bulhões 1480, 21041-210 Rio de Janeiro, RJ, Brasil *Departamento de \\ Protozoologia, Instituto Oswaldo Cruz-Fiocruz, Rio de Janeiro, RJ, Brasil **Laboratoire de Paléoparasitologie, CNRS ESA \\ 8045, Université de Reims, Reims, France ***School of Natural Resource Sciences, University of Nebraska-Lincoln, \\ Lincoln, USA
}

The parasite-host-environment system is dynamic, with several points of equilibrium. This makes it difficult to trace the thresholds between benefit and damage, and therefore, the definitions of commensalism, mutualism, and symbiosis become worthless. Therefore, the same concept of parasitism may encompass commensalism, mutualism, and symbiosis. Parasitism is essential for life. Life emerged as a consequence of parasitism at the molecular level, and intracellular parasitism created evolutive events that allowed species to diversify. An ecological and evolutive approach to the study of parasitism is presented here. Studies of the origin and evolution of parasitism have new perspectives with the development of molecular paleoparasitology, by which ancient parasite and host genomes can be recovered from disappeared populations. Molecular paleoparasitology points to host-parasite co-evolutive mechanisms of evolution traceable through genome retrospective studies.

Key words: evolution - paleoparasitology - parasitism - infectious diseases - ancient DNA - origin of parasitism

\section{PARASITISM}

A broad definition of parasitism would include all varieties of inter-specific associations in a gradient of interdependence. Therefore, associations defined as commensalism, mutualism and symbiosis are distinct features of a same phenomenon - parasitism.

The host-parasite-environment system is extremely dynamic and several balance points in this system are reached during its mutual evolution. Any attempt to define the limits of each kind of association as well as the limits between benefits and harm is worthless. Indeed, in nature these boundaries are indistinct and unsteady since they are distinct aspects of the same parasitism phenomenon.

In parasitism, in common with any other biocenosis (Rohde 1994a), an ecological niche is defined as being an n-dimensioned hypervolume that is bordered by the tolerance limits of the species (Hutchison 1980). Parasitism is an ecological phenomenon (Zelmer 1998), and as such it will be discussed here from an ecological and evolutionary point of view. Consequently, parasites $(\pi \alpha \rho \ddot{U} \sigma \iota \tau o \zeta ;$ para $=$ near; sitos $=$ food $)$ are defined as any life form - or any organic compound capable to multiply that find their ecological niche in another living form. In this context, an ecological niche includes all limits of environmental variations - biotic and abiotic - where one species adapts and reproduces.

Supported by CNPq/Pronex, Capes/Cofecub, Papes/Fiocruz, Fulbright Commission.

${ }^{+}$Corresponding author. Fax: +55-21-2598.2610. E-mail: adauto@ensp.fiocruz.br

Received 26 August 2002

Accepted 25 November 2002
Symbiosis was defined by de Bary (1879) as an assemblage of distinct organisms living together. As properly mentioned a hundred years later by Whitfield (1979), the elegant general term created by de Bary includes the vast majority of interspecific associations between organisms. It does not mention the way in which these organisms live, nor the effects, whether harmful, beneficial or any other. Whitfield (1979) called the different qualifications created to specify high or low levels of benefit or harm a semantic anarchy, thus rendering the term symbiosis almost useless.

Leuckart (1879) defined parasites as organisms that find in another organisms their habitat and nourishment. According to Brumpt (1913), parasites are all living beings, plants or animals, that during at least part of their lives depend upon another organism. Many parasites may be considered as harmless or even necessary for their hosts. On the other hand, one very important feature to be considered refers to the injuries that normally freeliving organisms may cause to other living forms that they eventually use as support - phoresys (Brumpt 1936). Thomas et al. (2000) reviewed parasitized and unparasitized populations where advantages were found in the first individuals.

Parasites and symbionts are generally defined as the two extremes of an interspecific interaction in which one of the partners is termed host, and the other, according to the degree of injury or benefit, is named parasite or symbiont (Caullery 1950).

The term parasite can be used without any connotation of pathogenicity or benefit to one or both partners in the association (Baker 1994). Thus focussed, the concepts of parasitism and symbiosis may be employed in the same sense since both refer to the same ecological and evolutionary feature. Moreover the classical definitions of mutualism, commensalism and symbiosis do not establish clear cut-offs that distinguish them from parasitism. 
Thus defined, parasitism comprises from molecular parasites to plants and vertebrate animals. The orchid mycorrhiza is in reallity a fungus parasitised by a plant (Corsaro et al. 1999), and some bird species are considered parasites because they use nests and parents of other bird species to raise their young (Smith 1979, Kruger \& Davies 2002).

A foetus is a parasite to the female body. If this recent evolutionary concept is accepted (Zelmer 1998), mammal evolution, for example, is in debt to a whole history of parasitism. The unicellular or multicellular body of any species of living organism is the consequence of the evolution of a community of parasites. This occurred from the molecular level to the formation of tissues by symbiogenesis (Margullis \& Chapman 1998, Ingber 2000).

\section{THE ORIGIN AND EVOLUTION OF PARASITISM}

Parasitism is inherent to life. Parasites are found in every organism of all existing species on earth (Poulin \& Morand 2000). Since the beginning of life parasitism was adopted by protorganisms to multiply. Actually parasitism must have occurred at an early stage of evolution (Bremermann 1983). All living organisms have a uniform biochemical composition that points to a common origin (Nasmith 1995) in a common ancestor that lived a billion years ago (Orgel 1998). Life on earth was only possible as a consequence of parasitism in what was still a molecular world. In fact, life appeared on earth around 4.4-3.8 billion years ago (Chang 1999, Nisbet \& Sleep 2001) as a consequence of molecular parasitism and the present day life forms still display relics of these ancient associations in their genomes (Galtier et al. 1999, Cavalier-Smith 2001).

Later diversification of life forms and species radiation was also the consequence of these multiple associations. These ancient events represent the first steps towards a host-parasite way of life although still at the level of molecules.

It is worth mentioning that the very first life forms in the so-called "RNA World" (Maynard-Smith \& Szathmáry 1993, Shapiro 1999, Poole et al. 1999) are still an issue under debate along with the other forms that appeared when life started (de Duve 1998, Shapiro 1999, 2000).

Associations recognized as a host-parasite systems existed since the very first gene associations, long before the appearance of the genetic code and gene translation (Maynard-Smith \& Szathmáry 1993). Parasitism has been an important promoter of biodiversity, commencing at the molecular level, the subsequent advent of the cell, and then followed by the development of the intracellular environment as an ecological niche.

Molecular parasitism is clearly exemplified by transposable elements of the genome. Indeed, the DNA sequences called transposable elements are actually recognized as molecular parasites (Doolittle et al. 1984, Kidwell \& Lisch 2001).

Transposable elements occur in both prokayotes and eukaryotes. Transposition is the insertion of an identical copy of the transposable element into a new genomic site of the host. These insertions can cause deletions, inversions, and chromosome fusions that result in considerable genome plasticity, thus contributing to biodiversity.
They have a common origin with viruses and retroviruses (Zaha 1996) and were identified first as 'control elements' by McClintock (1984).

The extra chromosomal transmissible genetic elements (viruses, plasmids and bacteriophages) are genome fragments that depend on the host cell to multiply and therefore they could not have preceded the cell itself (Lederberg 1997). These elements could have been the origin of nuclear DNA as well as other cellular organelles (Lederberg 1998). The extra chromosomal genetic elements and the transposable elements represent relics of primitive molecular parasites. They played a very important role in the evolution of life forms since their inclusion in the hosts' genomes' cell promoted genetic diversity. Certainly many of the alterations they induced were deleterious, but a number of them resulted in advantages for their hosts (Sverdlov 1998).

In viruses, genomic parasites can also be found and have been termed 'satellite' based on the satellite-like discovered by Kassinis (1962) in some cultures of tobaco necrosis virus (Mayo et al. 1999). Some are relatively benign and seem to be well adapted to the host, but others can cause deleterious effects. Mayo et al. (1999) emphasized virus relationships. They stated that the evolutionary process that led to viruses is complex and that it is impossible to define when a molecule is a 'commensal', when it is a 'parasite' when it is a 'symbiont', and when it becomes a part of the genome of the virus.

A failed episode of predation/parasitism resulted in the eukaryotic cell (Corsaro et al. 1999). Also, the prokaryotic cell exhibits clearly the parasitism that once was the causal effect of their origin (Lake et al. 1988). Not only the nucleous but also the whole cell is a chymera, a polyheterogenic state derived from a long history of parasite associations. The association of microorganisms that resulted in mitochondria, chloroplasts and other organelles granted a significant increase in the complexity of the living organisms that resulted in the improvement of their capacity to occupy new ecological niches (Andersson et al. 1998, Roger et al. 1998). Furthermore, the advent of the cell offered possible new niches for parasites (Thompson 1999).

Species vary in the degree to which they are subject to parasitism (John 1997). The perpetuation of life depends on the fine-tuning of the dialetic 'conservation versus change' (Radman et al. 1999), where the parasitehost ecological relationship plays an essential role. Divergent interests of each partner of the system result in selective pressures that may or may not result in fitness for the partners (Combes 2000). Fitness is only possible if parasitism is suitable.

\section{VIRULENCE}

At present, studies of host-parasite interactions include mainly the follow up of virulence and pathogenicity of a given infectious disease. Virulence is the ability of the parasite to multiply, and is under natural selection pressure to increase transmission success (Poulin \& Combes 2000). Pathogenicity refers to aspects of the hostparasite association that results in damage to the host. Pathogenicity is a property of the host-parasite associa- 
tion and not a characteristic of the parasite alone (Poulin \& Combes 1999). However, some use pathogenicity in the same sense of virulence (Lenski \& May 1994). Virulence may also be defined as a process where parasites are responsible to mediate morbidity and mortality in infected hosts (Levin 1996).

For the purpose presented here, virulence - the ability to multiply and transmit genes - and pathogenicity the capacity to induce morbility and mortality in a host population - are two different features.

It has been postulated that a high virulence and pathogenicity indicates that a given host-parasite association is a recent event. Nevertheless, an evolutionary approach to the phenomenon suggested that natural selection might favor virulence depending on the epidemiology and ecology of the parasite (Ewald 1996). Natural selection does not always favor peaceful coexistence (Cockburn 1963, Ewald 1995, Giorgio 1995, May \& Novak 1995, Levin 1996). Indeed, virulence can, and sometimes is, a fitness trait of the parasite. The proliferation rate of a parasite (virulence) is accepted as one critical factor for parasite success (Frank 1996).

The most virulent parasite will probably become the predominant form in a given niche, therefore enhancing its chances of dissemination in nature. Yet on the other hand, both parasite and host will be exterminated if this increase of virulence occurs at the expense of the host before the parasite reaches transmission. In addition, the defensive control measures developed by the host to resist parasites - the immune system - should be taken into account. Parasites, for their part, develop evasive mechanisms (DosReis 2000) and the result of this competition will define the success or failure of the host-parasite subsystem.

Many variables have to be deeply studied before one can forecast the fate of a given host-parasite sub-system. Parasitic population composition (Wilson et al. 2002), the presence of other parasitic species (multiple infections) in competition, or on the contrary, in cooperation (Mouritsen 2001) are some of the factors that should be taken into account as well as the direct energetic cost to the host of mounting an immune response (Rigby et al. 2002). Qualitative and quantitative response (Gandon \& Michalakis 2000), and the costs and consequences of sterilizing immunity versus tolerance of low-level infections in a host-parasite sub-system also need to be evaluated.

Studies on evolution of virulence should consider the transmission mode (vertical or horizontal) since transmission strategy is of fundamental importance (Poulin 1995,1996). In eurixene (eclectic) parasites, if virulence and transmission are linked characters, virulence may be considered as a fitness trait even if transmission requires the killing of the infected host. Leaving the "transmission problem" aside, genes that code for virulence may be advantageous for other aspects of the parasite, not related to transmission (see Poulin \& Combes 1999 who contest a gene of virulence). Some parasites enhance their virulence and pathogenicity after serial passages and others attenuate. Single infection, coinfection, and superinfection are also considered (Mosquera \& Adler 1998). Parasites that alter the host behavior, making the host susceptible to predation, may eliminate and be eliminated or, on the contrary, adapt to a new host. Some alter host growth, reproduction and survival; some can induce parthenogenesis, feminization of genetic males, and cause other bizarre effects in their hosts (Agnew et al. 2000, Bandi et al. 2001). All these variables make it difficult to forecast the fate of a given host parasite sub-system and point to the need for a detailed understanding of a parasites life cycle. Evolution occurs in both the parasite population and the host's immune system (Levin et al. 1999).

Certainly, during millions of years many host-parasite sub-systems perished but many survived and acquired advantages from the association while others are still adjusting before our eyes in a seemingly endless race. Successful host-parasites systems will always occur, and will certainly be preserved since they are the key of life. Pathological outcomes are therefore the result of many features and are always modulated by the responses of a living being confronting to a non-self element (DuBois 1959).

\section{PARASITES AND INFECTIOUS DISEASES}

Parasitic infections and parasitic disease are two strikingly distinct situations originated from a single process. A parasite is a necessary but not sufficient condition to launch a parasitic disease (Ferreira 1973). Parasitism does not necessarily result in injury or benefit to the host. Parasitic disease is an eventual outcome of a given parasite in a given host from a given population in a certain environment during a particular life co-evolution period of both protagonists. In essence it is a unique result of association of parasite and host in a given environment. It matters not whether a molecular parasite or a multi-cellular parasite is involved.

A system is formed by the parasite, the host, and the environment where each one interacts and influences the other subsystem in such a way that any change in one subsystem affects the other two (Ferreira 1973). Systems may exhibit order spontaneously. For example, in the physical world oil drops are spherical and snowflakes show 6-fold symetry not because selection has made them so, but because of inherent properties of the system (Kauffman 1993). Rohde (1997) discussed the system theory applied to parasitism: a species is a cloud in phenotypic space and a species evolution is a cloud 'walk' across that multidimensional space. As the complexity of a system increases, selection is progressively less able to change its properties. Applied to parasites, "species will at first explore many alternative routes, but subsequently they may become better adapted to individual host species. They can long-jump to other species only with increasing delays and ultimate stasis. The result is that many peaks (host species or habitats on or in the host) are never reached, with many vacant niches or phenotypic space largely empty" (see Rohde 1997 for details and empirical evidence).

Submitted to natural selection and/or the inherent properties of a system, the parasite-host-environment system reacts to changes in each subsystem with different responses, according to the features of the stimulus. Such a stimulus can induce parasitic disease originated by any 
component of a subsystem. Parasitic disease is not an umbalanced occurence in the host-parasite-environment relationship, but a natural phenomenon where some event has altered a component of the system and a specific reaction of a given individual host express signals and symptoms of a modified behavior of the whole system, i.e. disease.

Considering the ecological niche as a multidimensional hypervolume determined by a number of environmental variables in which a species can exist (Hutchinson 1980), and accepting the concept of parasitism where the parasite finds in the host its ecological niche, a parasitic disease is an expected event whenever one of the variables hinders or damages the parasite or the host, or when the environment is modified. Niches are not static. Host and microhabitat specificity, for example, may be affected by the age of host and parasite, presence or absence of other competitive parasite species, and the numbers of parasite individuals present. Host specificity, one of the many niche dimensions, is often determined by ecological factors (Holmes \& Bethel 1981, Rohde 1994b).

The history of evolution and biodiversity is fundamentally a history of evolution of species interactions (Thompson 1999). An isolated individual is only an abstraction and cannot be conceived out of its environment (Perestrello 1958).

Parasites promoted the major factors that have influenced the organization and evolution of life (Thomas et al. 1996). Zelmer (1998) proposed an evolutionary definition of parasitism. He used arguments of Read (1970) to discuss the failure to produce generalising concepts as a failure of the methods to approach the phenomenon of symbiosis as a special interaction between species. He concludes by placing all parasites within a shared evolutionary framework, with the host immune response as a constant and powerful selective factor. He criticizes the view of transition of phoresysis or commensalism to parasitism as a definitive modification of the nature of a given symbiotic relationship (Zelmer 1998).

\section{PARASITE EVOLUTION AND PALEOPARASITOLOGY}

Many significant remnants in the genome of parasites and hosts are left during the co-evolution process of a host-parasite-environment system. These remnants are transmitted in the genome and can reveal important features of the whole process.

Paleoparasitology and especially molecular paleoparasitology offer new tools for the study of host-parasiteenvironment systems since they offer the unique possibility of working with ancient parasites themselves. Paleoparasitology may shed light upon features concerning the antiquity of a given host-parasite complex as well as their origin and evolution (Araújo \& Ferreira 2000).

Parasites are believed to leave no fossils (Cameron 1952). Nevertheless parasitic remains have been found in paleontological sites, 1,5 million years old as well as in 500,000 years old preserved organic material (Ferreira et al. 1993, Jouy-Avantin et al. 1999). Parasites and their remnants can be detected in dried or mineralized coprolites, in archaeological or paleontological sites, and inside mummified corpses. In these remains, parasites may be studied in the same way as any other ancestral living form.

The introduction of molecular tools significantly opened this field of study. The adaptation of PCR to ancient DNA has already made possible the diagnosis of several infectious diseases in prehistoric populations, but the development of both new methods, and adjustments to the routinely used molecular procedures are still required to study this unique material (Araújo et al. 1998, Rollo \& Marota 1999, Orlando \& Hänni 2000). The absence of a complete fossil record of ancestral assemblages hampers studies of host phylogeny and ecology in determining parasite community richness (Vickerey \& Poulin 1998).

Mammalian trypanosomes offer a suitable example of how molecular paleoparasitology studies may clarify epidemiological and biological features. Kinetoplastids are distinguished by a single mitochondrion near the basal body of the flagellus, with species that parasitized plants and animals, but includes free-living taxa of the family Bodonidae (Maslov et al. 2001). The evolution of parasitism in trypanosomatids involves monogenetic and digenetic cycles. Phylogenetic studies dated trypanosomatid divergences prior to the origins of both current insect vectors (30-60 million years before present for tse-tse fly), and placental mammalian hosts ( $<85$ million years ago) (Fernandes et al. 1993).

The trypanosomes must evade host defences that vary from arthropods or other invertebrate vectors to the bloodstream or the intracellular habitat of vertebrate hosts. The evolutive history of trypanosomes have some recent elucidative studies showing that the Salivaria group (Trypanosoma brucei) diverge in a mid-Cretaceous date, around 100 million years ago, when Africa was totally separated from South America and Euroamerica (Haag et al. 1998). The cruzi clade has a southern super-continent (South America-Australia-Antarctica) origin, based on the inclusion of Australian marsupial trypanosomes on the clade (Stevens et al. 1998, 2001, Stevens \& Gibson 1999).

T. brucei co-evolved in Africa with the first hominids at 5 million years ago, but $T$. cruzi contact with human host is considered to have occurred in South America only after permanent settlements were made by previously nomadic cultures (Rothhammer et al. 1985, Coimbra Jr 1988, Stevens et al. 1998). Chagas disease is believed to have spread through the Americas, originating in the Andean countries as a consequence of the domiciliation of Triatoma infestans. In this context, descriptions of Chagas disease lesions in pre-Colombian mummies and positive PCR reactions for T. cruzi in tissues of 4,000 year old mummies, confirmed the antiquity of human infection by this parasite in the Americas (Rothammer et al. 1985, Guhl et al. 1997, 2000, Ferreira et al. 2000).

Moreover, another hypothesis should be considered suggesting that Chagas disease is as ancient as humans in Americas. According to findings in an archeological site in Piauí, Northeast of Brazil, the very first human settlements occurred in this locality, 50,000 years ago (Guidon \& Arnaud 1991, Parenti et al. 1998). Many radiocarbon dates from Northeastern Brazil, ranging from 10,000 to 20,000 years ago have been tabulated by Martin (1997). Caves and rock-shelters containing numerous 20,000- 
year-old rock-paintings attest their first occupation. It is therefore tempting to suggest that the artists of those paintings, and other cave inhabitants, were the first humans exposed to triatomine bugs (T. brasiliensis) and consequently to Chagas disease. This problem still occurs among archeologists during field studies in this area.

This hypothesis is partially supported by the recent molecular data on the diversity and origin of $T$. cruzi that recognizes Didelphis marsupialis as the first mammalian host of subpopulation $T$. cruzi I which is mainly associated with the enzootic transmission cycle. $T$. cruzi II is presented as having its evolutionary history related to primates and caviomorph rodents (Briones et al. 1999). In this scenario it is worth emphasizing that primates and caviomorph rodents were introduced to the Americas arriving from Africa 40-35 million years ago (Flynn \& Wissar 1998). Furthermore caviomorph rodents (Kerodon rupestris and Trichomys apereoides) and primates (Callitrichidae and Cebidae) are important inhabitants of rock shelters and caves of the above mentioned area where they probably acquired the infection from a preexisting transmission cycle.

A similar question remains unsolved in relation to Trypanosoma evansi, a salivarian trypanosomatid. In spite of being mechanically transmitted through tabanids, $T$. evansi belongs to the T. brucei clade. In the Pantanal region, Northwest of Brazil, T. evansi is responsible for a severe horse disease, "Mal de Cadeiras" that results in heavy economical losses. Its main sylvatic reservoir is the capybara, Hidrochoeris hidrochoeris, a large caviomorph rodent. The introduction of this trypanosomatid in the Americas is considered as a consequence of the introduction of infected horses by Spanish settlers in the fifteenth century. Nevertheless, one issue remains unanswered. It is known that T. evansi is a pathogenic trypanosome and it is hard to believe that infected horses could have supported the long and tough journey of those days without dying. It is easier to suppose a much earlier introduction of $T$. evansi along with caviomorph rodents during the Africa-America split.

Despite the absence of a well documented fossil record (Stevens et al. 2001), protozoa have been found in archaeological material (Ferreira et al. 1992): amastigote pseudocysts were found by Fornaciari et al. (1992), antigens were identified (Allisson et al. 1999), and DNA recovered from mummified bodies (Cantarino et al. 1998, Ferreira et al. 2000, Guhl et al. 2000).

With the recognition of the importance of understanding parasite evolution in the control of modern diseases (Ewald 1996, Ewald et al. 1998), paleoparasitology has a new importance. The understanding of parasite evolution can be addressed by the combined approaches of paleoparasitology and molecular paleoparasitology. With paleoparasitology, one can document the appearance of parasites in human prehistory. With molecular paleoparasitology, one can potentially identify the change in parasite genomes that resulted from the host-parasiteenvironment evolutionary system.

Without a doubt, infectious diseases have change through pre-historic times to present days (Leal \& Zanotto 2000). These included changes in virulence and pathoge- nicity that were associated with the progressive developments of civilization. The papers presented in this volume address the role of paleoparasitology in tracing the evolution of parasitism.

\section{REFERENCES}

Agnew P, Koella C, Michalakis Y 2000. Host life history responses to parasitism. Microbes Infect 2: 891-896.

Allison MJ, Bergman T, Gerszten E 1999. Further studies on fecal parasites in antiquity. Am Soc Clin Pathol 112: 605-609.

Andersson SGE, Zomorodipour A, Andersson JA, SicheritzPontén T, Alsmark UCM, Podowski RM, Näslund AK, Eriksson AS, Winkler HH, Kurland CG 1998. The genome sequence of Rickettsia prowazekii and the origin of mitochondria. Nature 396: 133-140.

Araújo A, Ferreira LF 2000. Paleoparasitology and the antiquity of human host-parasite relationshhips. Mem Inst Oswaldo Cruz 95 (Suppl. I): 89-93.

Araújo A, Reinhard K, Bastos OM, Costa LMC, Pirmez C, Iñiguez A, Vicente AC, Morel CM, Ferreira LF 1998. Paleoparasitology: perspectives with new techniques. Rev Inst Med Trop São Paulo 40: 371-376.

Baker JR 1994. The origins of parasitism in the protists. Int $J$ Parasitol 24: 1131-1137.

Bandi C, Dunn AM, Hurst GD, Rigaud T 2001. Inherited microorganisms, sex-specific virulence and reproductive parasitism. Trends Parasitol 17: 88-94.

de Bary HA 1879. Die Erscheinung der Symbiose, Karl J Tübner, Strassburg.

Bremermann HJ 1983. Parasites at the origin of life. J Math Biol 16: 165-180.

Briones MRS, Souto RP, Stolf BS, Zingales B 1999. The evolution of two Trypanosoma cruzi subgroups inferred from rRNA genes can be correlated with the interchange of American mammalian faunas in the Cenozoic and has implications to pathogenicity and host specificity. Mol Bioch Parasitol 104: 219-232.

Brumpt E 1913. Précis de Parasitologie, Masson, Paris.

Brumpt E 1936. Précis de Parasitologie, Vol. 2, Masson, Paris.

Cameron TWM 1952. Parasitism, evolution and phylogeny. Endeavour 11: 193-199.

Cantarino L, Araújo A, Sabroza P, Fernandes O, Pirmez C, Ferreira LF 1998. Leishmania amazonensis in taxidermized rodents. Mem Inst Oswaldo Cruz 93: 182-183.

Caullery M 1950. Le Parasitisme et la Symbiose, G Doin \& Cie, Paris, 358 pp.

Cavalier-Smith T 2001. Obcells as proto-organisms: membrane heredity, lithophosphorylation, and the origins of the genetic code, the first cells, and photosynthesis. J Mol Evol 53: 555-595.

Chang S 1999. Planetary environments and the origin of life. Biol Bull 196: 308-310.

Cockburn A 1963. The Evolution and Eradication of Infectious Diseases, The Johns Hopkins Press, Baltimore, 255 pp.

Coimbra Jr CEA 1988. Human settlements, demographic pattern, and epidemiology in Lowland Amazonia: the case of Chagas disease. Am Anthropol 90: 82-97.

Combes C 2000. La pression selectif dans le système parasitehôte. J Soc Biol 194: 19-23.

Corsaro D, Venditti D, Padula M, VAlassina M 1999. Intracellular life. Crit Rev Microbiol 25: 39-79.

Doolittle WF, Kirkwood TBL, Dempster MAH 1984. Selfish DNAs with self-restraint. Nature 307: 501-502.

DosReis GA 2000. Susceptible hosts: a resort for parasites right in the eye of the immune response. An Acad Bras $\mathrm{Ci}$ 72: $78-82$. 
DuBois R 1959. Mirage of Health - Utopias, Progress and Biological Change, Anchor Books, Donbleday Inc, New York.

de Duve C 1998. Réflexions sur l'origine et l'évolution de la vie. C R Soc Biol 192: 893-901.

Ewald PW 1995. The evolution of virulence: a unifying link between parasitology and ecology. J Parasitol 8: 659-669.

Ewald PW 1996. Evolution of Infectious Disease, Oxford Univ Press, Oxford, p. 3-13

Ewald PW, Sussman JB, Distler MT, Libel C, Chammas PW, Dirita VJ, Salles A, Vicente AC, Heitmann I, Cabello F 1998. Evolutionary control of infectious disease: prospects for vectorborne and waterborne pathogens. Mem Inst Oswaldo Cruz 93: 567-576.

Fernandes AP, Nelson K, Beverley SM 1993. Evolution of nuclear ribosomal RNAs in kinetoplastid protozoa: perspectives on the age and origins of parasitism. Proc Natl Acad Sci USA 90: 11608-11612.

Ferreira LF 1973. O fenômeno parasitismo. Rev Soc Bras Med Trop 4: 261-277.

Ferreira LF, Araújo A, Confalonieri U, Chame M, Ribeiro BM 1992. Eimeria oocysts in deer coprolites dated from 9,000 years B.P. Mem Inst Oswaldo Cruz 87: 105-106.

Ferreira LF, Araújo A, Duarte AN 1993. Nematode larvae in fossilized animal coprolites from lower and middle pleistocene sites, Central Italy. J Parasitol 79: 440-442.

Ferreira LF, Britto C, Cardoso MA, Fernandes O, Reinhard K, Araújo A 2000. Paleoparasitology of Chagas disease revealed by infected tissues from Chilean mummies. Acta Trop 75: 79-84.

Fornaciari G, Costagna M, Viacava P, Tognetti A, Bevilacqua G, Segura E 1992. Chagas disease in Peruvian Inca mummy. The Lancet 339: 128-129.

Flynn JJ, Wyss AR 1998. Recent advances in South American mammalian paleontology. Tree 13: 449-454.

Frank AS 1996. Models of parasite virulence. Quater Rev Biol 71: $37-78$.

Galtier N, Tourasse N, Gouny M 1999. A nonhyperthermophilic common ancestor to extant life forms. Science 283: 220221.

Gandon S, Michalakis Y 2000. Evolution of parasite virulence against qualitative or quantitative host resistence. Proc $R$ Soc Lond B Biol Sci 267: 985-990.

Giorgio S 1995. Moderna visão da evolução da virulência. Rev Saúde Pública 29: 398-402.

Guhl F, Jaramillo C, Vallejo GA, Arroyo FC, Aufderheide A 2000. Chagas disease and human migration. Mem Inst Oswaldo Cruz 95: 553-555.

Guhl F, Jaramillo C, Yockteng R, Vellejo GA, Arroyo FC 1997. Trypanosoma cruzi DNA in human mummies. The Lancet 349: 1370.

Guhl F, Vellejo GA, Yockteng R, Cardenas-Arroyo F, Fornaciari G, Arriaza B, Aufderheide AC 1999. Isolation of Trypanosoma cruzi DNA in 4,000-year-old mummified human tissue from Northern Chile. Am J Phys Anthropol 108: 401407.

Guidon N, Arnaud B 1991. The chronology of the New World: two faces of one reallity. World Archaeol 23: 524-529.

Haag J, O’Huigin C, Overath P 1998. The molecular phylogeny of trypanosomes: evidence for an early divergency of the Salivaria. Mol Bioch Parasitol 91: 37-49.

Holmes JC, Bethel WM 1972. Modification of intermediate host behaviour by parasites. In EU Canning, CA Wright (eds), Behavioural Aspects of Parasite Transmission, Academic Press, London, p. 317-376.

Hutchinson GE 1980. An Introduction to Population Ecology, Yale Univ Press, New Havenand, London, 260 pp.
Ingber DE 2000. The origin of cellular life. Bioessays 22: 11601170.

John JL 1997. The Hamilton-Zuk theory and initial test: an examination of some parasitological criticisms. Int $J$ Parasitol 27: 1269-1288.

Jouy-Avantin F, Combes C, Lumley H, Miskosky JC, Mone H 1999. Helminth eggs in animal coprolites from a Middle Pleistocene site in Europe. J Parasitol 85: 376-379.

Kassinis B 1962. Properties and behaviour of a virus depending for its multiplication on another. J Gen Microbiol 27: 477488.

Kauffman SA 1993. The Origins of Order. Self-organization and Selection in Evolution, Oxford University Press, New York.

Kidwell MG, Lisch DR 2001. Perspective: transposable elements, parasitic DNA, and genome evolution. Int J Org Evolution 55: 1-24.

Kruger O, Davies NB 2002. The evolution of cuckoo parasitism: a comparative analysis. Proc $R$ Soc Lond B Biol Sci 269: 375-381.

Lake JA, de la Cruz VF, Ferreira PCG, Morel CM, Simpson L 1988. Evolution of parasitism: kinetoplastid protozoan history reconstructed from mitochondrial rRNA gene sequences. Proc Natl Acad Sci USA 85: 4779-4783.

Leal ES, Zanotto PMA 2000. Viral diseases and human evolution. Mem Inst Oswaldo Cruz 95: 193-200.

Lederberg J 1997. Infectious disease as an evolutionary paradigm. Em Infec Dis 3: 417-423.

Lederberg J 1998. Emerging infections: an evolutionary perspective. Em Infec Dis 4: 366-371.

Lenski RE, May RM 1994. The evolution of virulence in parasites and pathogens: reconciliation between two competing hypothesis. J Theor Biol 169: 253-265.

Leuckart R 1879-1901. Die Parasiten des Menschen und die von ihnen herrüherenden Krankheiten, 2nd ed., Leipzig, p. 856-897.

Levin BR 1996. The evolution and maintenance of virulence in microparasites. Em Infec Dis 2: 93-102.

Levin BR, Lipsitch M, Bonhoeffer S 1999. Population biology, evolution, and infectious disease: convergence and synthesis. Science 283: 806-809.

Margulis L, Chapman MJ 1998. Endosymbioses: cyclical and permanent in evolution. Trends Microbiol 6: 342-346.

Martín G 1997. Pré-História do Nordeste do Brasil, Univ. Fed. Pernambuco, Recife, 445 pp.

May RM, Nowak MA 1995. Coinfection and evolution of parasite virulence. Proc R Soc Lond 261: 209-215.

Maslov DA, Podlipaev SA, Lukeš J 2001. Phylogeny of the Kinetoplastida: taxonomic problems and insights into the evolution of parasitism. Mem Inst Oswaldo Cruz 96: 397402.

Maynard-Smith J, Szathmáry E 1993. The origin of chromosomes I. Selection for likage. J Theor Biol 164: 437-446.

Mayo MA, Talliansky ME, Fritsch C 1999. Large sattelite RNA: molecular parasitism or molecular symbiosis. Curr Top Microbiol Immunol 239: 65-79.

Mclintock M 1984. The significance of reponses of the genome to challenge. Science 226: 792-801.

Mouritsen KN 2001. Hitch-hiking parasite: a dark horse may be the real rider. Int J Parasitol 31: 1417-1420.

Mosquera J, Adler FR 1998. Evolution of virulence: a unified framework for coinfection and superinfection. J Theor Biol 195: 293-313.

Nasmith K 1995. Evolution of the cell cycle. Phil Trans R Soc Lond 349: 271-281.

Nisbet EG, Sleep NH 2001. The habit and nature of early life. Nature 409: 1083-1091. 
Orgel LE 1998. The origin of life - a review of facts and speculations. TIBS 23: 491-495.

Orlando L, Hänni C 2000. Du nouveau pour l' ADN ancien. Soc Fr Gén 16: 1-16.

Parenti F, Fontugne M, Guidon N, Guérin C, Faure M, Debard E 1998. Chronostratigraphie des gisements archéologiques et paléontologiques de São Raimundo Nonato (Piauí, Brésil): contribution a la connaissance du peuplement pléistocène de l'Amérique. Actes du Colloque C14 Archéologie, p. 327 332.

Perestrello D 1958. Medicina Pscicossomática, Borsoi, Rio de Janeiro.

Poole A, Jeffares D, Penny D 1999. Early evolution: prokaryotes, the new kids on the block. BioEssays 21: 880-889.

Poulin R 1995. Evolution of parasite life history traits: miths and reality. Parasitol Today 11: 342-345.

Poulin R 1996. The evolution of life history strategies in parasitic animals. Adv Parasitol 37: 107-134.

Poulin R, Combes C 1999. The concept of virulence: interpretations and implications. Parasitol Today 15: 474-475.

Poulin R, Combes C 2000. The concept of virulence - Reply. Parasitol Today 16: 218.

Poulin R, Morand S 2000. The diversity of parasites. $Q$ Rev Biol 75: 277-293.

Radman M, Matic I, Taddei F 1999. Evolution and evolvability. Ann NY Acad Sci 18: 146-155.

Read CP 1970. Parasitism and Symbiology, Ronald Press Co., New York.

Rigby MC, Hechinger RF, Stevens L 2002. Why should parasite resistence be costly? Trends Parasitol 18: 116-120.

Roger AJ, Svärd SG, Tovar J, Clark CG, Smith MW, Gillin FD, Sogin ML 1998. A mitochondrial-like chaperonin 60 gene in Giardia lamblia: evidence that diplomonads once harbored an endosymbiont related to the progenitor of mitochondria. Proc Natl Acad Sci USA 95: 229-234.

Rohde K 1994a. Niche restriction in parasites: proximate and ultimate causes. Parasitology 109: S69-S84.

Rohde K 1994b. The origins of parasitism in the Platyhelminthes. Int J Parasitol 24: 1099-1115.

Rohde K 1997. The origins of parasitism in the Platyhelminthes: a summary interpreted on the basis of recent literature. Int J Parasitol 27: 739-746.

Rolo F, Marota I 1999. How microbial ancient DNA, found in association with human remains, can be interpreted. Phil Trans $R$ Soc Lond B 354: 111-119.
Rothhammer F, Allison MJ, Nuñez L, Staden V, Arriza B 1985. Chagas disease in pre-Columbian South America. Am J Phys Anthropol 68: 495-498.

Shapiro R 1999. Prebiotic cytosine synthesis: acritical analysis and implications for the origin of life. Proc Natl Acad Sci USA 96: 4396-4401.

Shapiro R 2000. A replicator was not involved in the origin of life. IUBMB Life 49: 173-176.

Sibley D, Haldar K 1999. Molecular parasitology goes cellular. Cell Microbiol 1: 259-262.

Smith NG 1979. Alternative responses by hosts to parasites which may be helpful or harmful. In BB Nickol, HostParasite Interfaces, Academic Press, NY, p. 7-15.

Stevens J, Gibson W 1999. The evolution of pathogenic trypanosomes. Cad Saúde Públ 15: 673-684.

Stevens J, Noyes H, Gibson W 1998. The evolution of trypanosomes infecting humans and primates. Mem Inst Oswaldo Cruz 93: 669-676.

Stevens JR, Noyes HA, Schofield CJ, Gibson W 2001. The molecular evolution of Trypanosomatidae. Adv Parasitol 48: $1-56$.

Sverdlov ED 1998. Perpetually mobile footprints of ancient infections in human genome. FEBS 428: 1-6.

Thomas F, Verneau O, De Meeús T, Renaud F 1996. Parasites as to host evolutionary prints: insights into host evolution from parasitological data. Int J Parasitol 26: 677-686.

Thomas F, Poulin R, Guegan JF, Michalakis Y, Renaud F 2000. Are the pros as well as cons to being parasitezed? Parasitol Today 16: 533-536.

Thompson JN 1999. The evolution of species interactions. Science 284: 2116-2118.

Vickery WL, Poulin R 1998. Parasite extinction and colonisation and the evolution of parasite communities: a simulation study. Int J Parasitol 28: 727-737.

Whitfield PJ 1979. The Biology of Parasitism: an Introduction to the Study of Associating Organisms, Edward Arnold, Great Britain.

Wilson K, Thomas MB, Blanford S, Doggert M, Simpson SJ, Moore SL 2002. Coping with crowds: density-dependent disease resistance in desert locust. Proc Natl Acad Sci USA 99: 5471-5475.

Zaha A 1996. Biologia Molecular Básica, Mercado Aberto, Porto Alegre, 336 pp.

Zelmer DA 1998. An evolutionary definition of parasitism. Int J Parasitol 28: 532-533. 